\title{
Molecular systematics of Thorea (Rhodophyta, Thoreales) species in Brazil
}

\author{
ORLANDO NECCHI JÚNIOR ${ }^{1,3}$, MARIANA CABRAL DE OLIVEIRA² ${ }^{2}$ and PATRÍCIA SALLES ${ }^{1}$
}

(received: October 23, 2008; accepted: March 18, 2010)

\begin{abstract}
Molecular systematics of Thorea (Rhodophyta, Thoreales) species in Brazil). This study aimed to evaluate species level taxonomy and phylogenetic relationship among Thorea species in Brazil and other regions of the world using two molecular markers - RUBISCO large subunit plastid gene $(r b c \mathrm{~L})$ and nuclear small-subunit ribosomal DNA (SSU rDNA). Three samples of Thorea from Brazil (states of Mato Grosso do Sul and São Paulo) and one sample from Dominican Republic (DR) were sequenced. Analyses based on partial sequences of $r b c \mathrm{~L}$ (1,282 bp) and complete sequences of SSU (1,752 bp) were essentially congruent and revealed that Thoreales formed a distinct monophyletic clade, which had two major branches with high support, representing the genera Thorea and Nemalionopsis. Thorea clade had four main branches with high support for all analyses, each one representing the species: 1) T. gaudichaudii C. Agardh from Asia (Japan and Philippines) - this clade occurred only in the $r b c \mathrm{~L}$ analyses; 2) T. violacea Bory from Asia (Japan) and North America (U.S.A. and DR); 3) T. hispida (Thore) Desvaux from Europe (England) and Asia (Japan); 4) a distinct group with the three Brazilian samples (sequence identity: rbcL 97.2\%, 1,246 bp; SSU 96.0-98.1\%, 1,699-1,720 bp). The Brazilian samples clearly formed a monophyletic clade based on both molecular markers and was interpreted as a separate species, for which we resurrected the name T. bachmannii Pujals. Morphological and molecular evidences indicate that the Thoreales is well-resolved at ordinal and generic levels. In contrast, Thorea species recognized by molecular data require additional characters (e.g. reproductive and chromosome numbers) to allow consistent and reliable taxonomic circumscription aiming at a world revision based on molecular and morphological evidences.
\end{abstract}

Key words - freshwater Rhodophyta, $r b c \mathrm{~L}$, SSU rDNA, Thorea, Thoreales

RESUMO - (Sistemática molecular de espécies de Thorea (Rhodophyta, Thoreales) no Brasil). Este estudo objetivou avaliar a taxonomia no nível específico e as relações filogenéticas entre as espécies de Thorea do Brasil e de outras regiões do mundo usando dois marcadores moleculares - genes plastidial da subunidade grande da RUBISCO $(r b c \mathrm{~L})$ e nuclear da subunidade pequena do DNA ribossômico (SSU rDNA). Três amostras de Thorea do Brasil (Estados de Mato Grosso do Sul e São Paulo) e uma amostra da República Dominicana (RD) foram sequenciadas. Análises baseadas nas sequências parciais de rbcL (1.282 pb) e completas de SSU (1.752 pb) foram essencialmente congruentes e revelaram que Thoreales formou um clado monofilético distinto, que teve dois ramos principais com alto suporte, representando os gêneros Thorea e Nemalionopsis. O clado de Thorea teve quarto ramos principais com alto suporte em todas análises, cada um representando as espécies: 1) T. gaudichaudii C. Agardh da Ásia (Japão e Filipinas); este clado ocorreu apenas nas análises de $r b c L$; 2) T. violacea Bory da Ásia (Japão) e América do Norte (E.U.A. e RD); 3) T. hispida (Thore) Desvaux da Europa (Inglaterra) e Ásia (Japão); 4) um grupo distinto com as três amostras do Brasil (identidade das sequências: rbcL 97,2\%, 1.246 pb; SSU 96,0-98,1\%, 1.699-1.720 pb). As amostras brasileiras formaram claramente um clado monofilético baseado nos dois marcadores moleculares e foi interpretado como uma espécie distinta, para a qual restabelecemos o nome T. bachmannii Pujals. Evidências morfológicas e moleculares indicam que Thoreales é bem resolvida nos níveis ordem e gênero. Em contrapartida, as espécies de Thorea reconhecidas por dados moleculares requerem caracteres adicionais (p.ex. reprodutivos e números de cromossomos) para permitir circunscrição taxonômica consistente e confiável visando revisão mundial baseada em evidências moleculares e morfológicas.

Palavras-chave - gene $r b c \mathrm{~L}$, Rhodophyta continental, SSU rDNA, Thorea, Thoreales

\section{Introduction}

The genus Thorea was proposed by Bory de Saint-Vicent (1808) and has been classified in the family

\footnotetext{
1. Universidade Estadual Paulista, Departamento de Zoologia e Botânica, Rua Cristóvão Colombo, 2265, 15054-000 São José do Rio Preto, SP, Brazil.

2. Universidade de São Paulo, Instituto de Biociências, Departamento de Botânica, Rua do Matão, 277, 05508-900 São Paulo, SP, Brazil.

3. Author for correspondence: orlando@ibilce.unesp.br
}

Thoreaceae of the order Batrachospermales (Sheath et al. 1993, Necchi Júnior \& Zucchi 1997, Entwisle \& Foard 1999). Thoreaceae is distinguished from the other members of the Batrachospermales basically by having multiaxial thalli (Sheath et al. 1993, Kumano 2002). The sequence data from the large subunit of ribulose 1,5-bisphosphate carboxilase/oxygenase $(r b c \mathrm{~L})$ and ribosomal DNA (small subunit, SSU rDNA) genes showed that Thorea does not appear to be a natural grouping within the Batrachospermales (Vis et al. 1998). The authors suggested that Thoreaceae should be elevated 
to ordinal status but still considered it as "incertae sedis" in the Florideophyceae. Müller et al. (2002) proposed the order Thoreales to accommodate the two recognized genera (Thorea and Nemalionopsis) based on DNA sequences of these two genes and ultrastructural features (pit plugs with two cap layers, the outer one typically plate-like). Thorea is distinguished by having assimilatory filaments not contained in a common gelatinous matrix with reproductive structures (carpogonia, spermatangia, carposporangia and monosporangia) at their base, whereas in Nemalionopsis they are embedded in a gelatinous matrix with reproductive structures at their apex (Sheath et al. 1993, Müller et al. 2002).

Members of the family are distributed worldwide but tend to be more common in tropical and subtropical regions or warm temperate waters (Sheath \& Hambrook 1990, Sheath et al. 1993, Carmona \& Necchi Júnior 2001). Thorea has been reported from several continents, whereas Nemalionopsis is known only from few localities in Asia and North America (Sheath et al. 1993, Müller et al. 2002). Only four species of Thorea were recognized worldwide by Sheath et al. (1993): T. clavata Seto et Ratnasabapathy, T. hispida (Thore) Desvaux, T. violacea Bory and T. zollingeri Schmitz. Entwisle \& Foard (1999) described T. conturba from Australia. Kumano (2002) recognized six additional species species in the world: T. bachmannii Pujals, T. brodensis Klas, T. gaudichaudii C. Agardh, T. okadaeYamada, T.prowsei Ratnasabapathy et Seto and. T. riekei Bischoff. Taxonomic characters used for species delineation include essentially vegetative features: plant length, branching (abundant or sparse secondary branches), size and shape of assimilatory filaments (clavate or nonclavate), size of assimilatory filaments and frequency of monosporangial clusters. This fact usually brings problems for species circumscriptions in the genus, which are still not satisfactorily resolved. Sexual reproduction, as well as the presence of juvenile gametophytes, have also been observed under natural conditions (Yoshizaki 1986, Necchi Júnior 1987, Sheath et al. 1993, Necchi Júnior \& Zucchi 1997, Entwisle \& Foard 1999) or in laboratory culture (Necchi Júnior \& Carmona 2002).

Populations of Thorea have been relatively well-documented in Brazil. Necchi Júnior (1987) described in detail the vegetative and reproductive features T. bachmannii. Necchi Júnior \& Zucchi (1997) followed the monographic treatment by Sheath et al. (1993) and regarded T. bachmannii as a synonym of T. violacea, and presented a full description, as well as environmental and geographical information. Necchi Júnior et al. (1999) reported T. violacea from hard water regions in São Paulo State, including environmental data. More recently, Carmona \& Necchi Júnior (2001) analyzed four populations from southeastern Brazil, together with others from Central Mexico. They regarded T. violacea as a synonym of T. hispida, since the most distinguishing character to separate them (secondary branching frequency) showed a considerable overlapping within a same population.

Considering the relatively poor knowledge on stability of taxonomic characters and distributional aspects for Thorea species worldwide, this study aimed to evaluate species level taxonomy and phylogenetic relationship among Thorea species in Brazil and other regions of the world using two genes - the plastid $r b c \mathrm{~L}$ and the nuclear SSU rDNA.

\section{Materials and methods}

Three samples of Thorea were analyzed from two out of the three regions where Thorea specimens had been reported from Brazil (Necchi Júnior 1987, 1989, Necchi Júnior \& Zucchi 1997, Carmona \& Necchi Júnior 2001) (table 1). An additional sample from Dominican Republic (from Culture Collection of Algae and Protozoa, CCAP, Oban, Scotland, UK) was also sequenced for comparison. Voucher specimens preserved in $4 \%$ formaldehyde were lodged at SJRP Herbarium (Holmgren \& Holmgren 1998). Fresh thalli were desiccated in silica gel and later kept frozen at $-20^{\circ} \mathrm{C}$. These samples were ground in liquid nitrogen and DNA was extracted using the NucleoSpin ${ }^{\circledR}$ Plant mini kit (MN - Macherey-Nagel, Düren, Germany) following the manufacturer's protocol.

Polymerase chain reactions (PCR) for both molecular markers were conducted with the "puReTaq Ready-to-go PCR beads" (GE Healthcare Life Sciences, Bucks, UK) for a total volume of $25 \mu \mathrm{L}$ consisting of $2 \mu \mathrm{L}$ of genomic DNA, $2 \mu \mathrm{L}$ of each primer, $19 \mu \mathrm{L}$ of Nuclease-free water. PCR reactions were performed in a Techne TCS-312 thermocycler (Techne, Cambridge, UK). The genes $r b c \mathrm{~L}$ and SSU rDNA were amplified using primers and cycles previously described (Vis et al. 1998, Vis \& Sheath 1999, Milstein \& Oliveira 2005). PCR product was purified using the QIAquick ${ }^{\circledR}$ kit (Qiagen) according to the manufacturer's protocol.

The double-stranded PCR products were sequenced using the ABI PRISM ${ }^{\circledast}$ Big Dye Terminator v3.0 Cycle Sequencing Ready Reaction Kit in the ABI PRISM 3100 Genetic Analyzer (Applied Biosystems, Foster City, U.S.A.). Sequencing reactions were performed using PCR amplification primers and internal primers (as listed in Vis et al. 1998, Vis \& Sheath 1999, Milstein \& Oliveira 2005) so that the entire fragment was sequenced in both directions. Consensus sequences were obtained for the $r b c \mathrm{~L}$ and SSU rDNA genes for the samples listed in table 1, encompassing 1,282 bp for $r b c \mathrm{~L}$ and 1,752 bp for SSU rDNA. For sample BO 8, the SSU rDNA sequence was 1,565 bp. Unfortunately, we were not able to get PCR products from samples BO 8 
Table 1. Sample information and GenBank accession numbers for $r b c \mathrm{~L}$ and SSU rDNA sequences of Thorea samples sequenced in this study.

\begin{tabular}{llc}
\hline Sample code & Collection information & $\begin{array}{c}\text { GenBank accession } \\
\text { number }^{2}\end{array}$ \\
\hline SP 64 & São Paulo State: Jumirim, 2 km from town, tributary of & GU953247 \\
& Sorocaba River, 2305’54” S, 4747’57” W, culture isolate & GU953243 \\
BO 5 & Mato Grosso do Sul State: Bodoquena, Campina & GU953248 \\
& Stream, 20²5’06” S, 5643’01” W, coll. O. Necchi Júnior, 30-V-2002 & GU953244 \\
BO 8 & Mato Grosso do Sul State: Bonito, Jenipapo Stream, & - \\
& 2059’07” S, 56²7’08” W, coll. O. Necchi Júnior, 01-VI-2002 & GU953245 \\
CCAP 1394/4 & Dominican Republic: San Cristobal, spring, 20¹8’00” N, & - \\
& $49^{\circ} 46^{\prime} 02^{\prime \prime}$ W, 1968, culture isolate & GU953246 \\
\hline
\end{tabular}

${ }^{1}$ Codes as used in figures 1-2. ${ }^{2}$ Numbers refer to $r b c L$ and SSU rDNA, respectively.

and CCAP 1394/4 (table 1). The consensus sequences were aligned using ClustalW in BioEdit 6.0 software (Hall 1999) and were manually inspected, including sequences from GenBank. Ballia callitricha (C. Agardh) Kützing (AF236790, AF149029) was used as outgroup in all analysis. The final alignment matrices contained 50 sequences belonging to 43 taxa and 1,202 positions for $r b c L$ and 27 sequences belonging to 20 taxa and 1,630 positions for SSU rDNA.

Phylogenetic analyses were performed with PAUP 4.0b8 (Swofford 2000) and MrBayes v3.1.2 (Ronquist \& Huelsenbeck 2003). The appropriate evolution model was selected using MrModeltest 2.2 (Nylander 2004) under the Akaike Information Criterion (AIC). For the Bayesian analysis two runs of four Markov chains over 4,000,000 generations sampling every 100 generations was employed. The initial 50,000 generations were discarded as burning. A neighborjoining (NJ) tree (Saitou \& Nei 1987) was built with Tamura \& Nei (1993) substitution model. A maximum parsimony (MP) tree was inferred by heuristic search, with starting trees obtained by stepwise addition, with random sequence addition (10 replicates) using the tree bisection-reconnection (TBR) branch-swapping algorithm. In both $\mathrm{NJ}$ and MP trees, gaps were treated as missing data and all sites were weighted equally. Bootstrap analyses (Felsenstein 1985) were performed with 2,000 replicates for the methods described above. Maximum likelihood (ML) analysis was performed with heuristic search using TBR algorithm, with starting trees obtained via stepwise addition as described for the MP tree. Bootstrap re-sampling was done for 100 replicates. For all analyses, support values were interpreted as follows (for bootstrap and posterior probability, respectively): low ( $<70 \%$ or 0.70$)$, moderate $(71-90 \%$, $0.71-0.90$ ) and high ( $>90 \%$ or 0.90$)$. For the $r b c \mathrm{~L}$ data set ML analyses were performed using GTR distance model with the same parameters as the NJ analysis estimated from Modeltest: base frequencies $\mathrm{A}=0.3732, \mathrm{C}=0.1053, \mathrm{G}=0.1777$ and $\mathrm{T}=0.3439$, rate matrix $\mathrm{A}-\mathrm{C}=4.5567, \mathrm{~A}-\mathrm{G}=5.8084$, $\mathrm{A}-\mathrm{T}=1.5908, \mathrm{C}-\mathrm{G}=1.6710, \mathrm{C}-\mathrm{T}=26.3251$ and $\mathrm{G}-\mathrm{T}=1.0000$, proportion of invariable sites $=0.5299$, gamma distribution $=$
0.9782. For SSU data set the following parameters were used: base frequencies $\mathrm{A}=0.2538, \mathrm{C}=0.2088, \mathrm{G}=0.2878$ and $\mathrm{T}=0.2497$, rate matrix $\mathrm{A}-\mathrm{C}=1.0443, \mathrm{~A}-\mathrm{G}=2.6035$, $\mathrm{A}-\mathrm{T}=1.0310, \mathrm{C}-\mathrm{G}=1.0731, \mathrm{C}-\mathrm{T}=4.6944, \mathrm{G}-\mathrm{T}=1.0000$, proportion of invariable sites $=0.6116$, and gamma distribution $=0.7557$.

\section{Results}

Analyses based on $r b c L$ sequences - Analyses based on partial sequences (tables 1-2, figure 1) showed that Thoreales formed a distinct monophyletic clade from the Batrachospermales. The clade for the Thoreales had two major branches with high support, representing the genera Thorea and Nemalionopsis (figure 1). Thorea clade had four main branches with high support based on the four methods of analyses, each one representing species: 1) T. gaudichaudii with three samples from Asia (Japan and Philippines); 2) T. violacea, with four samples from Asia (Japan) and North America (U.S.A. and Dominican Republic, including one sample of T. riekei); 3) T. hispida, with six samples from Europe (England) and Asia (Japan, including two samples of T. okadae and one as T. violacea); this clade had moderate support (86\%) for ML but high for the other three analyses; 4) a distinct clade with the two Brazilian samples. Minor clades within species also had high support, except for the two samples of T. gaudichaudii (AB159650 e AB159651), with moderate support. The sequences for the two Brazilian samples exhibited high identity (97.2\%, 1,246 bp.) The interspecific variation between the Brazilian samples and the closely related species T. hispida ranged from 83.5 to 91.3\%, 1,070-1,170 bp (table 2). Thus, and the Brazilian samples were regarded as a single and separate species. 


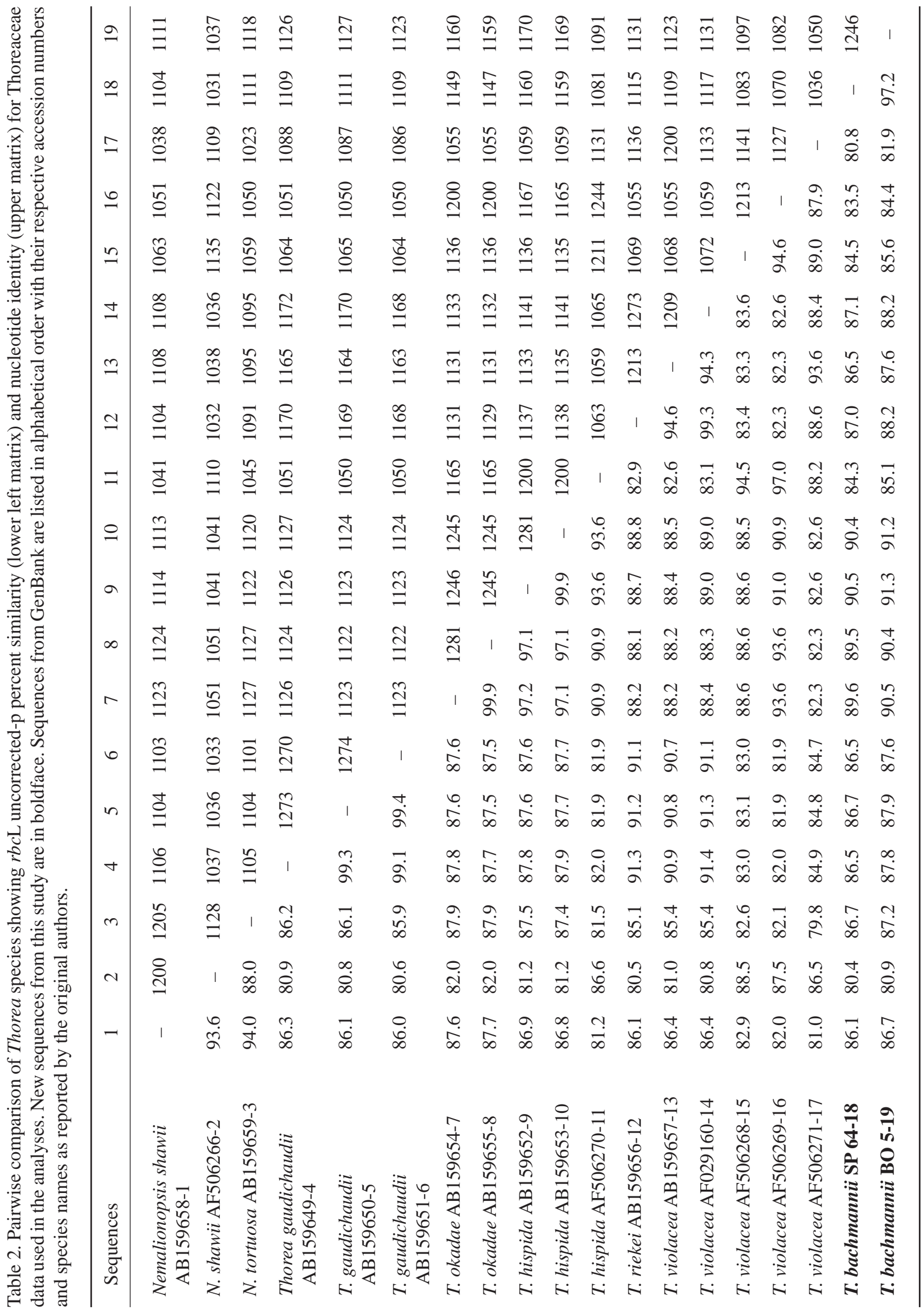


Ballia callitricha AF149029

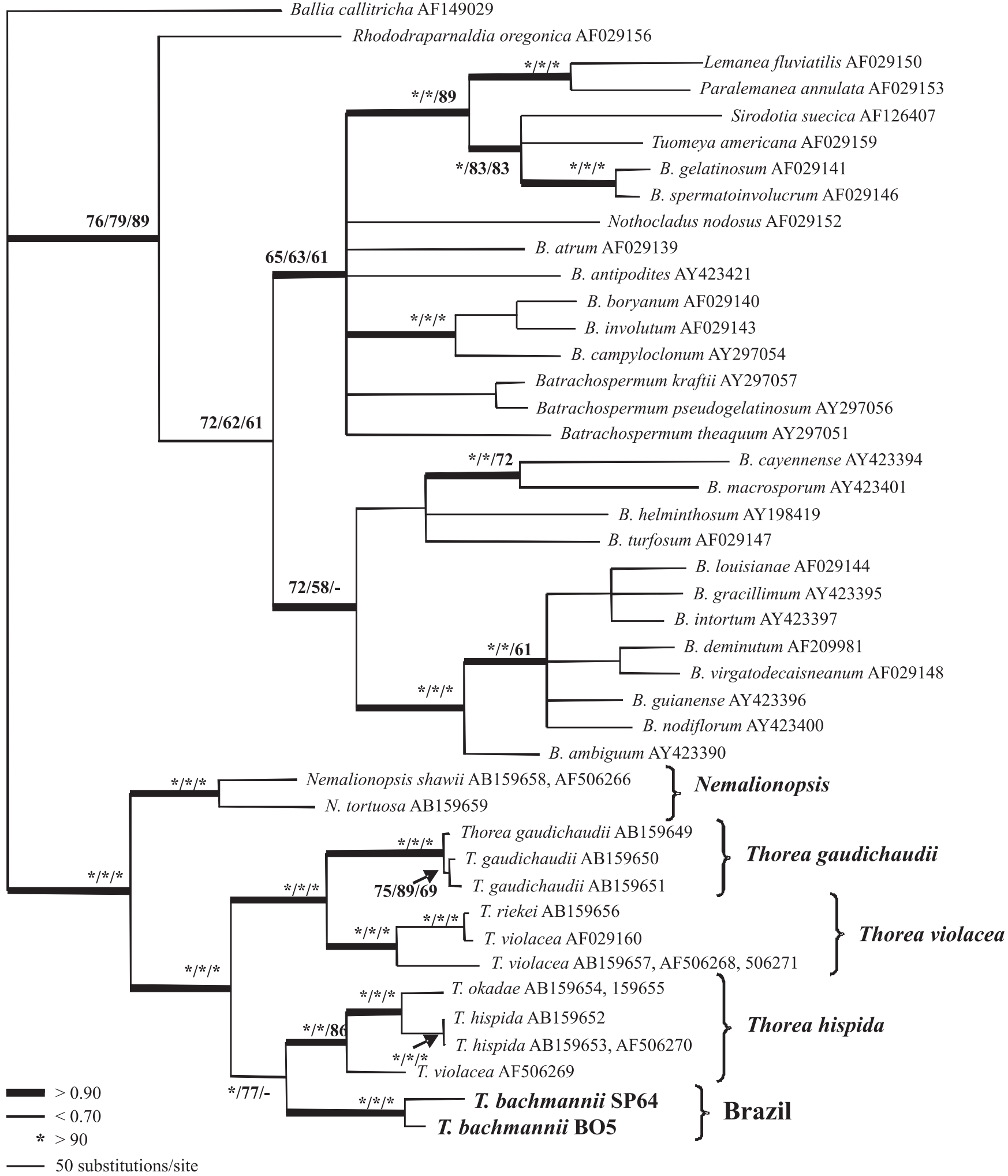

Figure 1. Maximum likelihood (ML) rbcL analysis tree showing the relationships of the samples from Brazil (larger and boldface) to previously sequenced taxa of Thoreales. Bootstrap support values for all analyses are shown on the branches as follows: neighbor-joining (NJ)/Maximum Parsimony (MP)/Maximum likelihood (ML) bootstraps. Bayesian posterior probabilities are shown as branches with distinct thickness (as indicated in the figure). 
Analyses based on SSU rDNA sequences - Analyses (tables 1, 3, figure 2) revealed that Thoreales formed a monophyletic clade apart from the Batrachospermales and within the Thoreales two major clades were formed with high support, representing the genera Thorea and Nemalionopsis (figure 2). Thorea clade had two main branches with high support, one representing $T$. violacea and the other included two closely related species (T. hispida and the Brazilian samples). The clade of T. violacea had four samples from North America (U.S.A., including the new sequence from Dominican Republic). The clade of T. hispida included three samples from Asia (Australia and Japan, as Thorea sp. and T. violacea, respectively) and Europe (England). The third clade included the three Brazilian samples. The sequences for Brazilian samples exhibited higher identity with one another (96.0-98.1\%, 1,699-1,720 bp) than to the closer related species T. hispida (90.5-95.5\%, 1,586-1,674 bp, table 3). In addition, this variation among sequences of the Brazilian samples was comparable to those observed within the other two species: T. hispida (95.4-99.3\%, 1,672-1739 bp) and T. violacea (95.3-99.3\%, 1,671$1,740 \mathrm{bp})$. Thus, the samples from Brazil were interpreted as representing a single and distinct species.

Table 3. Pairwise comparison of Thorea species showing SSU rDNA uncorrected-p percent similarity (lower left matrix) and nucleotide identity (upper matrix) for Thoreaceae data used in the analyses. New sequences from this study are in boldface. Sequences from GenBank are listed in alphabetical order with their respective accession numbers and species names as reported by the original authors.

\begin{tabular}{|c|c|c|c|c|c|c|c|c|c|c|c|c|}
\hline Sequences & 1 & 2 & 3 & 4 & 5 & 6 & 7 & 8 & 9 & 10 & 11 & 12 \\
\hline $\begin{array}{l}\text { Nemalionopsis tortuosa } \\
\text { AF342743-1 }\end{array}$ & - & 1714 & 1604 & 1697 & 1704 & 1595 & 1639 & 1671 & 1697 & 1625 & 1639 & 1629 \\
\hline N. shawi AF506272 - 2 & 97.8 & - & 1620 & 1681 & 1686 & 1611 & 1653 & 1651 & 1672 & 1602 & 1616 & 1611 \\
\hline T. hispida AF506273 - 3 & 91.5 & 92.4 & - & 1615 & 1618 & 1739 & 1674 & 1685 & 1613 & 1595 & 1613 & 1622 \\
\hline T. violacea AF342744 - 4 & 96.8 & 95.9 & 92.1 & - & 1740 & 1604 & 1681 & 1679 & 1727 & 1630 & 1641 & 1630 \\
\hline T. violacea AF026042 - 5 & 97.2 & 96.2 & 92.3 & 99.3 & - & 1608 & 1683 & 1686 & 1730 & 1639 & 1650 & 1637 \\
\hline T. violacea AF506274 - 6 & 91.0 & 91.9 & 99.2 & 91.5 & 91.7 & - & 1664 & 1672 & 1602 & 1586 & 1604 & 1629 \\
\hline T. violacea AF506275 - 7 & 93.5 & 94.3 & 95.5 & 95.9 & 96.0 & 94.9 & - & 1622 & 1671 & 1574 & 1588 & 1590 \\
\hline Thorea sp. AF420253 - 8 & 95.3 & 94.2 & 96.1 & 95.8 & 96.2 & 95.4 & 92.5 & - & 1342 & 1662 & 1674 & 1660 \\
\hline $\begin{array}{l}\text { Thorea violacea } \\
\text { CCAP 1394/4 - } 9\end{array}$ & 96.8 & 95.4 & 92.0 & 98.5 & 98.7 & 91.4 & 95.3 & 95.7 & - & 1634 & 1643 & 1637 \\
\hline $\begin{array}{l}\text { Thorea bachmannii } \\
\text { SP } 64 \text { - } 10\end{array}$ & 92.7 & 91.4 & 91.0 & 93.0 & 93.5 & 90.5 & 89.8 & 94.8 & 93.2 & - & 1699 & 1683 \\
\hline $\begin{array}{l}\text { Thorea bachmannii } \\
\text { BO } 5-11\end{array}$ & 93.5 & 92.2 & 92.0 & 93.6 & 94.1 & 91.5 & 90.6 & 95.5 & 93.7 & 96.9 & - & 1720 \\
\hline $\begin{array}{l}\text { Thorea bachmannii } \\
\text { BO } 8-12\end{array}$ & 92.9 & 91.9 & 92.5 & 93.0 & 93.4 & 92.9 & 90.7 & 94.7 & 93.4 & 96.0 & 98.1 & - \\
\hline
\end{tabular}

\section{Discussion}

In previous phylogenetic analyses of the Thoreales (Vis et al. 1998, Müller et al. 2002) it consistently appeared as well-supported clade, as well as the two genera (Thorea and Nemalionopsis). Likewise, in the present study, the order and its two genera were confirmed and further supported with the addition of two new $r b c \mathrm{~L}$ and four new SSU rDNA sequences (three from Brazil and one from Dominican Republic). Thoreales is distinguished from members of the sister group Batrachospermales by having multiaxial thallus construction (Sheath et al. 1993,
Kumano 2002). The two genera in the Thoreales can be separated on reliable morphological characters: Thorea has reproductive structures (carpogonia, spermatangia, carposporangia and monosporangia) positioned at the base of assimilatory filaments that are not contained in a common gelatinous matrix, whereas in Nemalionopsis reproductive structures are at the apex of assimilatory filaments, which are embedded in a gelatinous matrix (Sheath et al. 1993, Müller et al. 2002).

Thus, the available morphological and molecular information indicates that the Thoreales is well-resolved at ordinal and generic levels. 
Rhodododraparnaldia oregonica AF026043

Audouinella hermannii AF026040

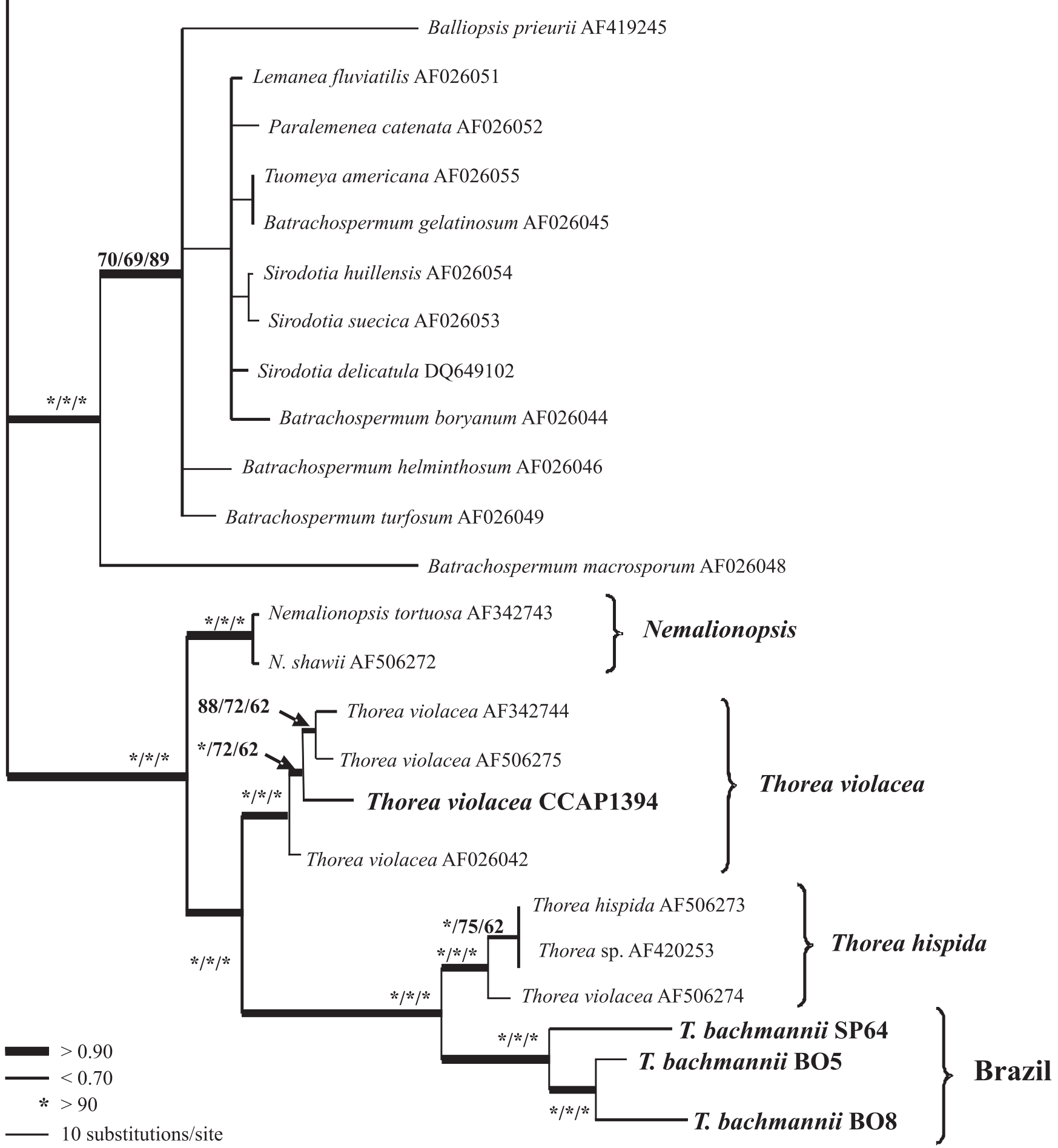

Figure 2. Maximum likelihood (ML) SSU rDNA analysis tree showing the relationships of the samples from Brazil (larger and boldface) to previously sequenced taxa of Thoreales. Bootstrap support values for all analyses are shown on the branches as follows: neighbor-joining (NJ)/Maximum Parsimony (MP)/Maximum likelihood (ML) bootstraps. Bayesian posterior probabilities are shown as branches with distinct thickness (as indicated in the figure). 
Molecular data based on the two markers used in this study were quite consistent and congruent at species level. The dataset for $r b c \mathrm{~L}$ covers a higher number of species and populations of each species and thus it is more representative. Four species can be recognized on the basis of molecular data: 1) T. gaudichaudii from Asia (Japan and Philippines, T. Hanyuda et al., unpublished data); 2) T. violacea - from Asia (Japan) and North America (U.S.A. and Dominican Republic) (T. Hanyuda et al., unpublished data, Müller et al. 2002, this study); 3) T. hispida - from Asia (Australia and Japan) and Europe (England) (T. Hanyuda et al., unpublished data, Müller et al. 2002, Saunders \& Necchi Júnior 2002); 4) the three Brazilian populations formed a highly supported and distinct clade. According to the taxonomic account by Sheath et al. (1993) based on morphology, we confirmed that T. riekei did not appear as a distinct entity, and should be considered as a synonym with $T$. violacea. However, samples of T. okadae from Japan (T. Hanyuda et al., unpublished data) did not form a separate branch, but grouped together with samples from Japan and England (Müller et al. 2002) and should be treated as a synonym of T. hispida and not of T. violacea as proposed by Sheath et al. (1993). Thorea violacea was considered as paraphyletic by Müller et al. (2002) because one sample (sequences AF506269 - rbcL and AF506274 - SSU) was associated with T. hispida, a result confirmed in this study. However, it would be presumably a case of misidentification of that particular sample, since all other populations of T. hispida and T. violacea grouped with their allies, as expected, including our new SSU sequence of T. violacea from Dominican Republic. The species here delineated partly agrees with the worldwide species treatment adopted by Kumano (2002) by recognition of T. gaudichaudii, T. hispida and T. violacea as distinct species. However, it differs in that present molecular data did not support the acceptance of T. okadae and T. riekei as distinct taxonomic entities at any rank (specific or infra-specific level).

The Brazilian samples clearly formed a distinct monophyletic clade based on both molecular markers and is here interpreted as a separate species. In the first unequivocal report of Thorea in Brazil (Necchi Júnior 1987, 1989) Brazilian specimens were identified as T. bachmannii, a species originally described from Argentina (Pujals 1967). The species was later considered as a synonym with T. violacea (Sheath et al. 1993), which has been followed by Necchi Júnior \& Zucchi (1997). Thorea bachmannii appeared as a sister group of T. hispida, with which it has been previously considered as a synonym (Carmona \& Necchi Júnior 2001). However, it is not closely related to $T$. violacea on the basis of $r b c \mathrm{~L}$ and SSU sequences, as it was previously assumed by Sheath et al. (1993) and Necchi Júnior \& Zucchi (1997) on a morphological ground. Kumano (2002) kept T. bachmannii as a separate species from T. hispida and T. violacea, which has good support from present molecular data. Thus, we resurrected the name T. bachmannii for the Brazilian populations as originally reported for specimens from São Paulo State (Necchi Júnior 1987, 1989).

A comparative study of other samples and species from across the world is expected to yield additional tools to separate species and to complement the DNA sequence data presented in this investigation. Considering that wide morphological and morphometrical variations have been reported for vegetative characters (Sheath et al. 1993, Carmona \& Necchi Júnior 2001, Kumano 2002), species description should include reproductive characters (carpogonia, spermatangia and carposporangia), which could serve as additional diagnostic characters (Yoshizaki 1986, Necchi Júnior 1987, Carmona \& Necchi Júnior 2001). Other features can be potentially used as well, e.g. chromosome numbers (Carmona \& Necchi Júnior 2001). A broad set of characters will possibly contribute towards more consistent and reliable species circumscriptions in Thorea. This will be a necessary step to accomplish a world revision of the genus and to test the classification scheme here adopted.

Acknowledgements - This paper was funded by CNPq (305153/2006-4) and Fapesp (04/06689-1) grants to the senior author and CNPq (301217/2007-6) grant to MCO. Aid is gratefully acknowledged from: M. Helena Carabolante in lab work; Sílvia R. Blanco in sequencing.

\section{References}

BORY DE SAINT-VINCENT, J.B. 1808. Mémoire sur un genre nouveau de la cryptogamie aquatique, nommé Thorea. Annales du Museum D’Histoire Naturelle 12:126-35.

CARMONA, J.J. \& NECCHI JÚNIOR, O. 2001. Systematics and distribution of Thorea (Thoreaceae, Rhodophyta) from Central Mexico and southeastern Brazil. Phycological Research 49:231-239.

ENTWISLE, T.J.\& FOARD, H. 1999. Freshwater Rhodophyta in Australia: Ptilothamnion richardsii (Ceramiales) and Thorea conturba sp. nov. (Batrachospermales). Phycologia 38:47-53.

FELSENSTEIN, J. 1985. Confidence limits on phylogenies: an approaching using bootstrap. Evolution 39:783-791. 
HALL, T.A. 1999. BioEdit: a user-friendly biological sequence alignment editor and analysis program for Windows 95/98/NT. Nucleic Acids Symposium Series 48:95-98.

HOLMGREN, P.K. \& HOLMGREN, N.H. 1998. [continuously updated]. Index Herbariorum: a global directory of public herbaria and associated staff. New York Botanical Garden’s Virtual Herbarium. http://sweetgum.nybg.org/ ih/. (acessed 2009 Dec 21).

KUMANO, S. 2002. Freshwater red algae of the world. Biopress, Bristol.

MILSTEIN, D. \& OLIVEIRA, M.C. 2005. Molecular phylogeny of Bangiales (Rhodophyta) based on small subunit rDNA sequencing: emphasis on Brazilian Porphyra species. Phycologia 44:212-221.

MÜLLER, K.M., SHERWOOD, A.R., PUESCHEL, C.M., GUTELL, R.R. \& SHEATH, R.G. 2002. A proposal of a new red algal order, the Thoreales. Journal of Phycology 38:807-820.

NECCHI JÚNIOR, O. 1987. Sexual reproduction in Thorea Bory (Rhodophyta, Thoreaceae). Japanese Journal of Phycology 35:106-12.

NECCHI JÚNIOR, O. 1989. Rhodophyta de água doce do estado de São Paulo: levantamento taxonômico. Boletim de Botânica da Universidade de São Paulo 11:11-69.

NECCHI JÚNIOR, O., BRANCO, C.C.Z. \& BRANCO, L.H.Z. 1999. Distribution of Rhodophyta in streams from São Paulo State, southeastern Brazil. Archiv für Hydrobiologie 147:73-89.

NECCHI JÚNIOR, O. \& CARMONA, J.J. 2002. Somatic meiosis and development of the juvenile gametophyte in members of the Batrachospermales sensu lato (Rhodophyta). Phycologia 41:340-347.

NECCHI JÚNIOR, O. \& ZUCCHI, M.R. 1997. Taxonomy and distribution of Thorea (Thoreaceae, Rhodophyta) in Brazil. Algological Studies 84:83-90.

NYLANDER, J.A.A. 2004. MrModeltest 2.2. Program distributed by the author. Evolutionary Biology Centre, Uppsala University, Upsalla.
PUJALS, C. 1967. Presencia en la Argentina del genero Thorea (Rhodophycophyta, Florideae). Comunicaciones del Museo Argentino de Ciencias Naturales 1:55-64.

RONQUIST, F. \& HUELSENBECK, J.P., 2003. Mr Bayes 3: Bayesian phylogenetic inference under mixed models. Bioinformatics 19:1572-1574.

SAITOU, N. \& NEI, M. 1987. The neighbor-joining method: a new method for reconstructing phylogenetic trees. Molecular Biology and Evolution 4:406-425.

SAUNDERS, G.W. \& NECCHI JÚNIOR, O. 2002. Nuclear rDNA sequences from Ballia prieurii support recognition of Balliopsis gen. nov. in the Batrachospermales (Florideophyceae). Phycologia 41:61-67.

SHEATH, R.G. \& HAMBROOK, J.A. 1990. Freshwater ecology. In Biology of the red algae (K.M. Cole \& R.G. Sheath, eds.). Cambridge University Press, Cambridge, p.423-53.

SHEATH, R.G., VIS, M.L. \& COLE, K.M. 1993. Distribution and systematics of the freshwater red algal family Thoreaceae in North America. European Journal of Phycology 28:231-241.

SWOFFORD, D.L. 2000. PAUP*. Phylogenetic Analysis Using Parsimony (* and other methods). Version 4. Sinauer Associates, Sunderland.

TAMURA, K. \& NEI, M. 1993. Estimation of the number of nucleotide substitutions in the control region of mitochondrial DNA in humans and chimpanzees. Molecular Biology and Evolution 10:512-526.

VIS, M.L., SAUNDERS, G.W., SHEATH, R.G., DUNSE, K \& ENTWISLE, T.J. 1998. Phylogeny of the Batrachospemales (Rhodophyta) inferred from $r b c \mathrm{~L}$ and 18S Ribossomal DNA gene sequences. Journal of Phycology 34:341-350.

VIS, M.L. \& SHEATH, R.G. 1999. A molecular investigation of the systematic relationships of Sirodotia species (Batrachospermales, Rhodophyta) in North America. Phycologia 38:261-266.

YOSHIZAKI, M. 1986. The morphology and reproduction of Thorea okadai (Rhodophyta). Phycologia 25:476-81. 